\title{
MEASUREMENT OF LATERAL EROSION AT PROPOSED RIVER CROSSING SITES OF THE ALASKA PIPELINE
}

\author{
by James Brice
}

THE UNITED STATES DEPARTMENT OF THE INTERIOR, GEOLOGICAL SURVEY Water Resources Division, Alaska District - 1971 


\section{CONTENTS}

Page

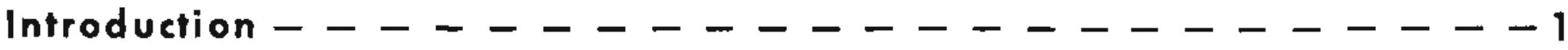

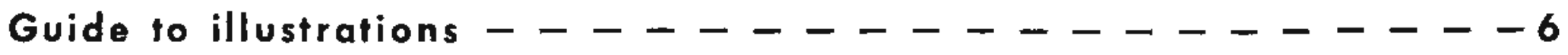

Proposed river crossings --------------7

Lowe River crossing ----------------7

Crossing of Sheep Creek fan, adjacent to Lowe River - - - - - 10

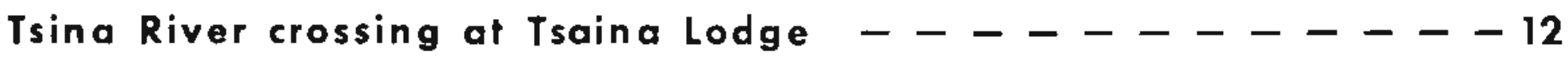

Tsina River crossing near mile $41------+----14$

Tonsing River crossing ---------------16

Klutina River crossing --------------18

Tazlina River crossing ---------------20 
CONTENTS - Continued

Page

Tazlina River meander - - - - - - - - - - - 22

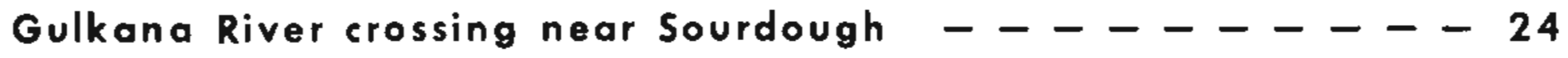

Galcha River crossing ---------------26

Chatanika River crossing ---------------28

Hess Creek crossing ----------------30

Jim River crossing ----------------32

Dietrich River crossing at Koyukuk River confluence - - - - 34

Sagavanirktok River crossing near Sagwon $---_{-}--_{-} 36$

Sagavanirktok River crossing af Ivishak River confluence - - 38 


\section{INTRODUCTION}

This study of lateral erosion rates by comparison of aerial photographs was undertaken at the request of D. M. Culbertson, hydraulic engineer, U.S. Geological Survey, Menlo Park, Calif., and preparatory work in Alaska (during June 1-18, 1971) was done with the cooperation of Harry Hulsing, district chief, Alaska District. Examination of river crossings between the Yukon River and Prudhoe Bay was done by helicopter, for the use of which I am indebted to Giles McDonald of the Bureau of Land Management. Most of the crossing sites described here were examined in the field, in too brief a time to permit quantitative measurements but long enough to be of much assistance in interpretation of the aerial photographs. Location of the earlier photographs with reference to the terrane was difficult because of the inaccuracy of existing index sheets, but it was greatly facilitated by Ray Krieg of the $R$ \& M Engineering Geological Consultants in Fairbanks and by personnel of the Alyeska Pipeline system Office in Anchorage. This report was prepared at Washington University in St. Louis, Mo., with support by Research Grant 8623-EN, Airphoto interpretation of the form and behavior of alluvial rivers, from the U.S. Army Research office in Durham, N. C. 
Where the proposed Alaskan pipeline is to be buried beneath stream channels, the design depth of burial should be greater than the estimated maximum depth of scour in the main channel of the stream. How far from the main channel this maximum depth of burial is to be maintained depends on estimates of the lateral rate and direction of migration of the main channel during the life of the pipeline, which is here taken to be 30 years. Where a stream is bordered by a flood plain or other low surface, the depth of burial of the pipeline beneath this surface depends on estimates of the maximum depth of scour to be expected during floods that may cover the surface.

For each crossing site, the distance of lateral migration by the river was measured by precise superposition and matching of aerial photographs taken about 20 years apart. Most of the earlier photographs were taken in 1950, but the earliest available photographs for two of the crossing sites (Jim and Dietrich Rivers) were taken in 1955. All of the later photographs were taken in 1969. Erosjon rates at specific localities are obtained by dividing the distance of migration by the time interval between photographs. These rates cannot be used for prediction of future rates because the 20-year period on which they are based may not include a representative number of high flows, during which most tateral erosion occurs. For most of the rivers at or near the crossing sites, the flow histories are either unknown or inadequate. Nevertheless, the measured rates of lateral erosion are the best available indication of future rates, and they also give a good indication of the specific localities along a bank where rapid future erosion is most probable. 
The river crossing site on each aerial photograph was copied photographically to produce a $35-\mathrm{mm}$ slide. The Alyeska mosaic was also copjed, because it shows the location of the pipeline and its scale is controlled. Two projectors, mounted side by side on a sliding track and fitted with 8 -cm projection lenses, were lised to project $35-\mathrm{mm}$ sljdes simultaneousiy on a rigid screen.

First the slide of the Alyeska mosaic (scale 1:12,000) was projected and the image of the 7969 photograph was matched for scale and position with that of the mosaic, by adjustments of distance, tilt, and rotation. When the two images were nearly matched, one of the images was caused to flicker by passing a card rapidly back and forth across the lens. If two reference points did not precisely match, their images appeared to flicker on the screen. When the images were satisfactorily matched, the pipeline route was traced on a sheet of paper taped to the screen.

Next the earlier aerial photograph was projected in place of the mosaic, and matched with the 1969 image. The image of the 1969 photograph was traced on the paper in black, and the image of the earlier stream course was traced in red.

Where scale distortions in one or the other of the photographs prevented matching of the entire image, as was commonly the case, the older image was matched to the newer and traced for successive short segments of the stream. Thus the lateral migration distance as traced is relatively accurate, even though the later photograph may be somewhat distorted in planimetric scale.

The error of the lateral-migration distance as obtained by matching of the photographs depends on the original scale and definition of the photographs, the scale of the projection, the degree of scale distortion in the photographs, the number 
and reliability of reference points, and the care used in matching. With care, the images could be matched on the screen to the nearest 0.05 inch. This amounts to an error of \pm 12 feet at a projected scale of $1: 3,000$, as was used for the Chatanika River, and an error of \pm 40 feet on a scale of $1: 9,000$, as was used for the Sagavanirktok River. Laterat migration rates tend to fncrease with the size of the river, so the percentage error remains about the same. In view of the generally small scale and poor definition of the earlier Alaskan aerial photographs, the error could not under any circumstances be reduced below 112 feet, and $I$ may be overly optimistic in this estimate.

As to the safe depth of burial of the pipeline beneath the flood-plain and low terrace surfaces along the rivers, this depends in part on the depth of scour to be expected on these surfaces during floods. Deep scour on the surfaces of flood plains or low terraces is usually associated with diversion of the main channel or a subsidiary channel across these surfaces. Study of the Alaskan rivers on aerial photographs indicates that diversion of channels across a bordering surface is more probable along the meandering rivers than along the braided rivers, for which no example of such diversion was observed. Along the meandering rivers, channel diversion occurs by chute or neck cutoff across an individual meander or, as in the case of Hess creek, by cutoff across the neck of a compound meander. In general, both the meandering and the braided rivers migrate by lateral bank erosion. However, diversion of a channet along the pipeline route is a distinct possibility, particularly where the route trends in the general flow direction of the river. 


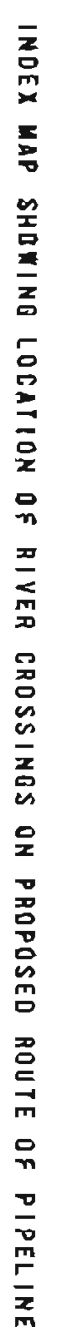
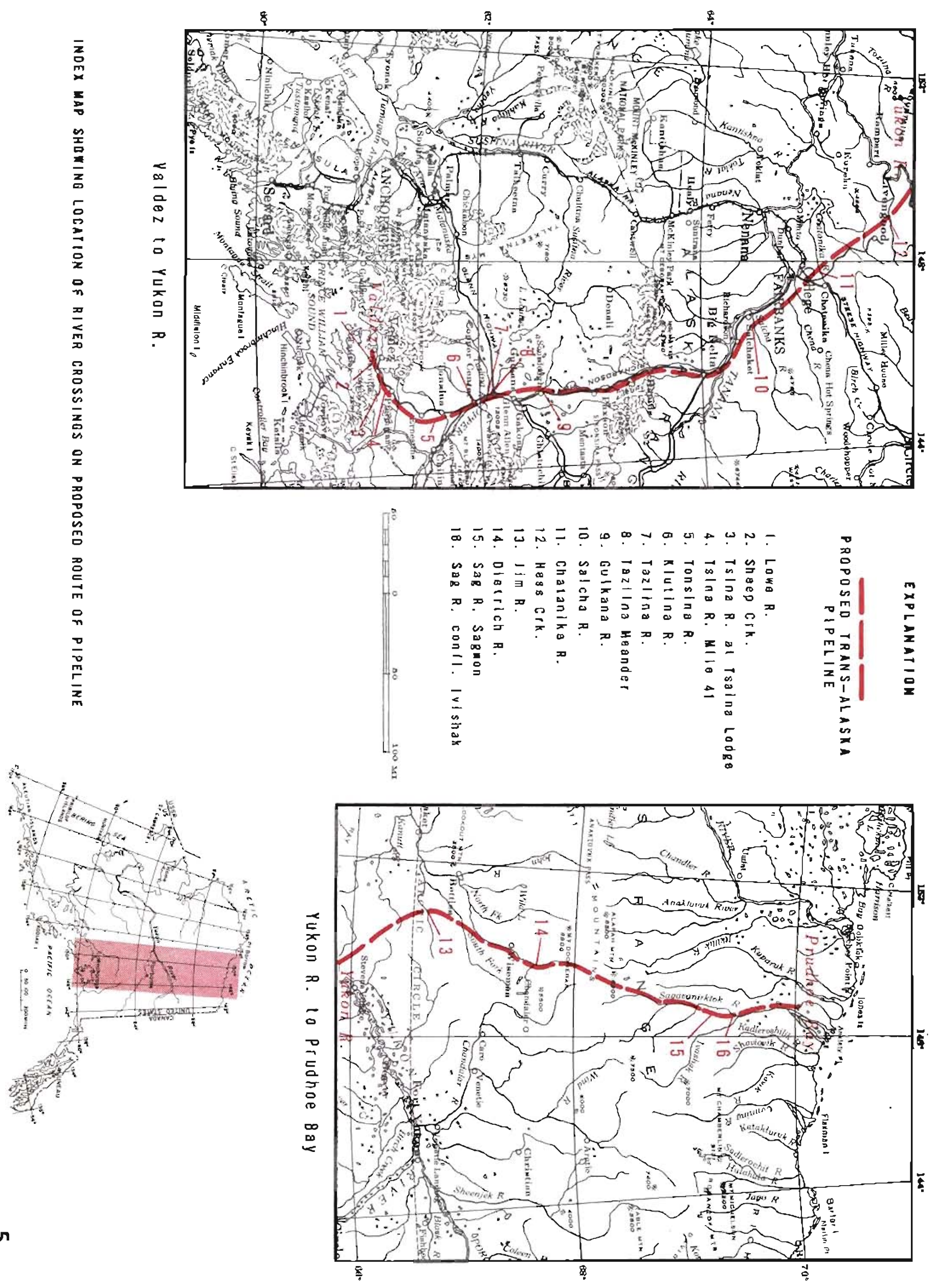


\section{GUIDE TO ILLUSTRATIONS}

The meaning of the colors and symbols on the maps is as follows:

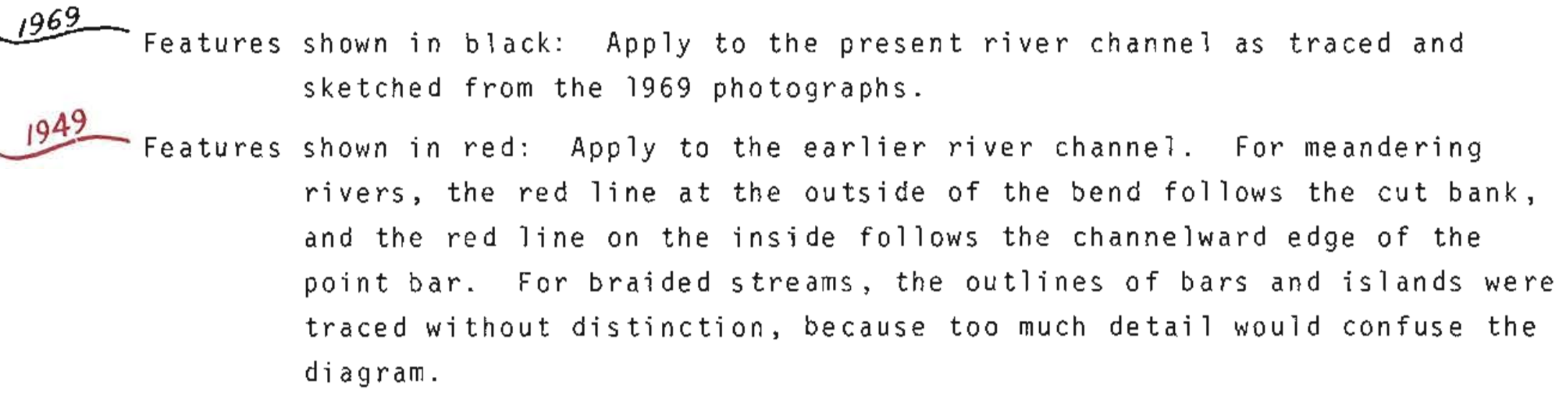

- $\triangle$ - Heavy black line: Proposed pipeline route, as shown on Alyeska photomosaics issued early in 1971 .

Dotted pattern: Bars or islands bare or sparsely vegetated, effectively a part of the drainage course.

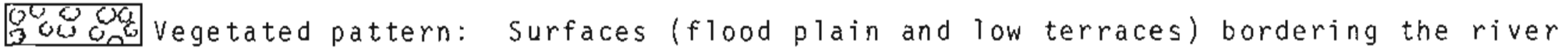
that are considered subject to flooding at recurrence intervals ranging from about 2 years to about 50 years. The symbol is not intended to mean that vegetation does not grow at other localities represented on the diagram.

Dashed pattern: Terraces and valleyside slopes considered not subject to flooding or, in the case of lower terraces, subject to flooding at rare intervals.

Red shaded areas: Areas of vegetated floodplain or terrace that have been removed by lateral erosion between the time of the earliest and of the latest photographs. 


\section{PROPOSED RIVER CROSSINGS}

\section{Lowe River Crossing}

The southern approach of the pipeline to the river channel is down the steep slope of the glacial trough occupied by the Lowe River and across a small fan made by a high-gradient tributary that courses down the valley side. The proposed pipeline route crosses the mouth of this tributary. As shown on the map, the tributary channel has shifted on the fan by about 100 feet between 1950 and 1969, although no shift is apparent between 1937, the date of an earlier photograph made by Bradford Washburn, and 1950. The fan itseif has been trimmed back about 25 feet by the Lowe Rjver, probably as a result of the construction of the Richardson Highway bridge, which diverted the course of the Lowe toward the south side of the valley. As the present river course is in approximate alignment with the bridge opening, not much further cutting of the fan is expected within the next few decades. Also, further significant shift of the drainage course on the fan seems unlikely, as it is rather deeply entrenched on the fan. If the pipeline were shifted a few tens of feet downstream from the tributary mouth, the potential for disruption by the tributary might be completely eliminated. 
The braided anabranches of the Lowe River have shifted generally to the south since 1950, probably as a result of construction of the bridge and highway. Some southerly shift is also apparent between 1937 and 1950. The present bridge and highway embankment will probably hold the river to approximately its present course at the pipeline crossing for the next few decades.

The geomorphic evidence suggests that scour to maximum depths of about 6 feet will occur from place to place on the sparsely vegetated gravel flats north of the present channel. This estimate is based on the study of abandoned scour channels. The bed material of the Lowe River is moderately coarse for Alaskan rivers; it ranges in size from boulders about 2 feet in diameter to sand and silt, with material in the pebble and small-cobble size range being most abundant. As the channels are not confined (except at the bridge opening), they probably will shift laterally rather than scouring deeply at any one locality. Lowe River channels of significant size are unlikely to occupy the forested area crossed by the pipeline north of the river. In the past, this area has been occupied by channels on the Sheep creek fan.

Terraces at various levels along Lowe River indicate that the recent history of the river has been one of degradation rather than aggradation, and the river is probably degrading 5 lowly at present. Shifts of the main channel by lateral bank erosion and the abandonment of anabranches are to be expected rather than by abrupt changes in course direction. 


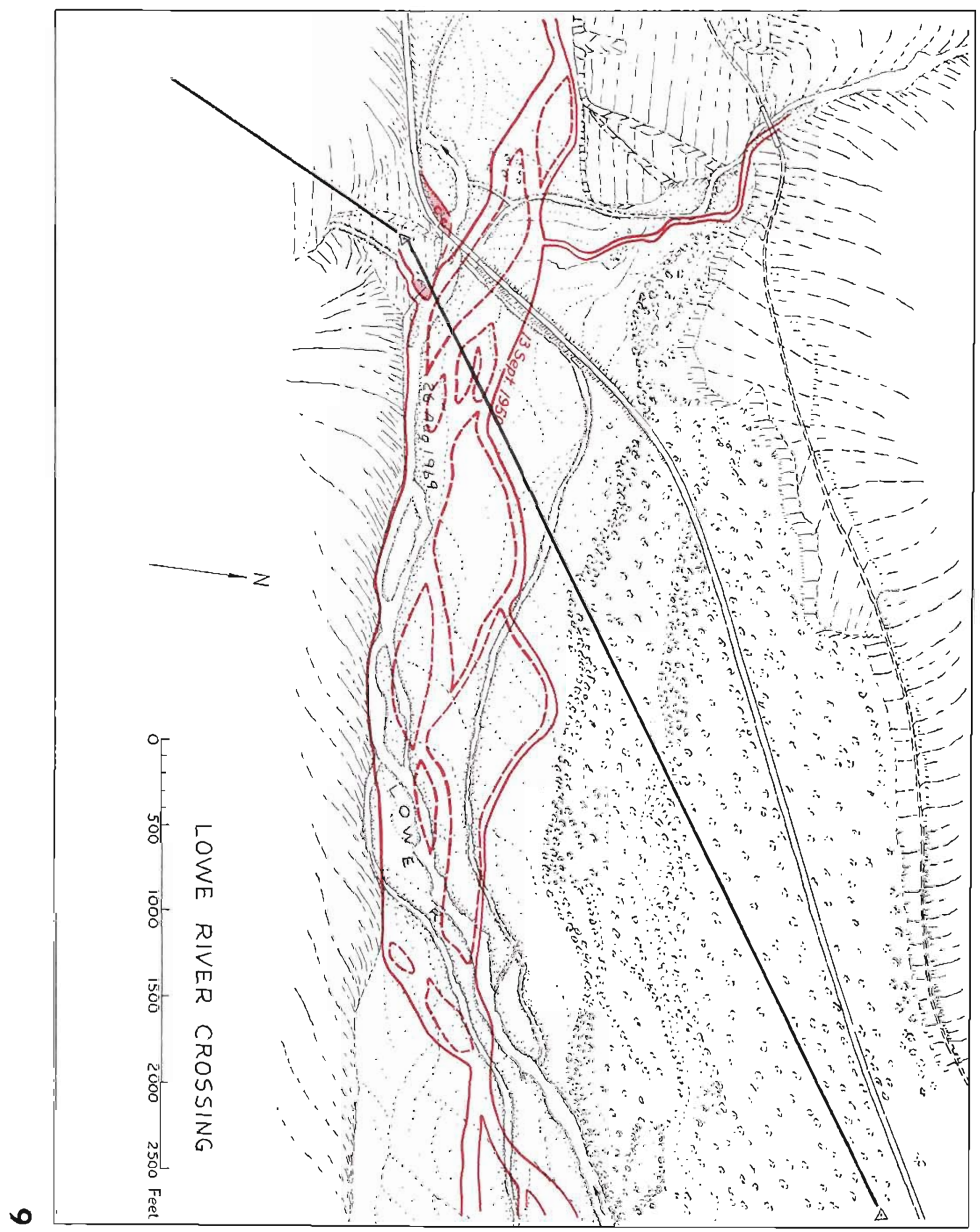




\section{Crossing of Sheep Creek Fan, Adjacent to Lowe River}

Sheep creek has a history of flooding resulting from the $i$ mpoundment and subsequent release of water by a glacier about 4 miles upstream from the pipeline crossing. The highway bridge upstream from the pipeline crossing has been replaced several times and the existing bridge was constructed about 1962 . Breakout of a glacier-dammed lake, probably on June 17, 1959 , was accompanied by a surge of rock debris that buried a grove of balsam poplar trees on the fan to a depth of about 8 feet. (See red circle beneath the date "26 Aug., 1969 " on map). Subsequent scour by the sheep creek channel has exhumed the trees to the same level at which they were originally growing. Several trees are still standing upright in the present channel, and one of these has adventitious roots marking the level to which it was buried. It is astonishing that any of these trees, which are only about 1 foot in diameter, could first be buried by a presumably high-velocity flood and then be exhumed without being uprooted or even tilted.

Between 1950 and 1969 , the channel of Sheep creek shifted about 200 feet at a point just upstream from the proposed crossing, although it has shifted only slightly at the crossing site. At the crossing site, banks of the channel are about 7 feet high. Future shifts of the channel are difficult to predict, particularly because the effects of glacial outbreaks are uncertain. Apparently, the effects of any outbreak in the period 1950-69 were depositional rather than erosional. If the next glacial outbreak should deposit debris to the north of the present channel (which seems likely, as this area is somewhat lower), the main channel couid well be diverted to the south along one of its prior courses. The sheep creek fan is distinctly asymmetrical, its southerly growth being favored both by the steep gradient of the Lowe River trough and the outbuilding of the Wortmanns creek fan on the opposite side of the Lowe River. 


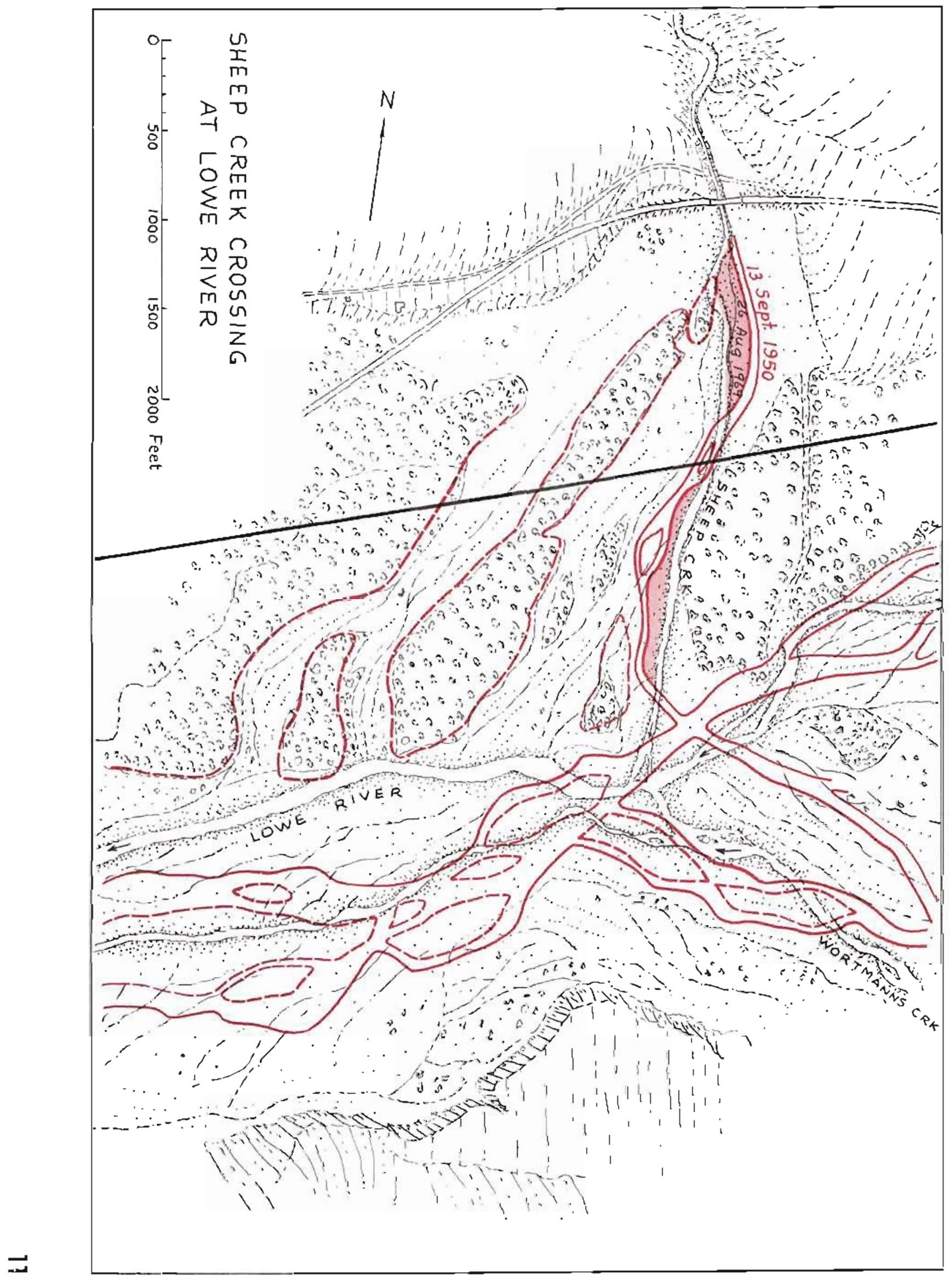




\section{Tsina River Crossing at Tsaina Lodge}

The course of the Tsina River is incised into the bottom of a glacial trough that follows the regional strike of metamorphic rocks (low grade mica schist or phylite). Just upstream from the crossing site, the channel cuts abruptry across the regional strike for about 1,500 feet, then turns abruptly again to follow the strike. The western approach of the pipeline to the channel is on bedrock and the eastern approach is across a terrace, which stands as a cut bank about 10 feet high on the right side of the channel.

Owing to the poor resolution and small scale of the 1950 photographs, lateral erosion at the crossing site could not be accurately measured. However, the cut bank in the terrace has receded no more than about 25 feet during the past 20 years.

Very high competence of the stream at the crossing site is indicated both by large imbricate boulders in the terrace fill and by the imbricate arrangement of schist blocks up to 5 feet long in and adjacent to the channel. Bedrock probably occurs beneath the channel at a depth of about 30 feet. This shallow depth to bedrock is predicted because of the close spacing of bedrock outcrops on either side of the channel downstream, which, as measured on the photographs, confine the channel to a width of about 20 feet. These downstream outcrops are presumably continuous at shallow depth, and form a local baselevel for the channe1. If that is so, it seems unlikely that the channel upstream at the crossing site is notched to any great depth below them. There is thus a good probability that the pipe could be set in bedrock at the crossing site. 


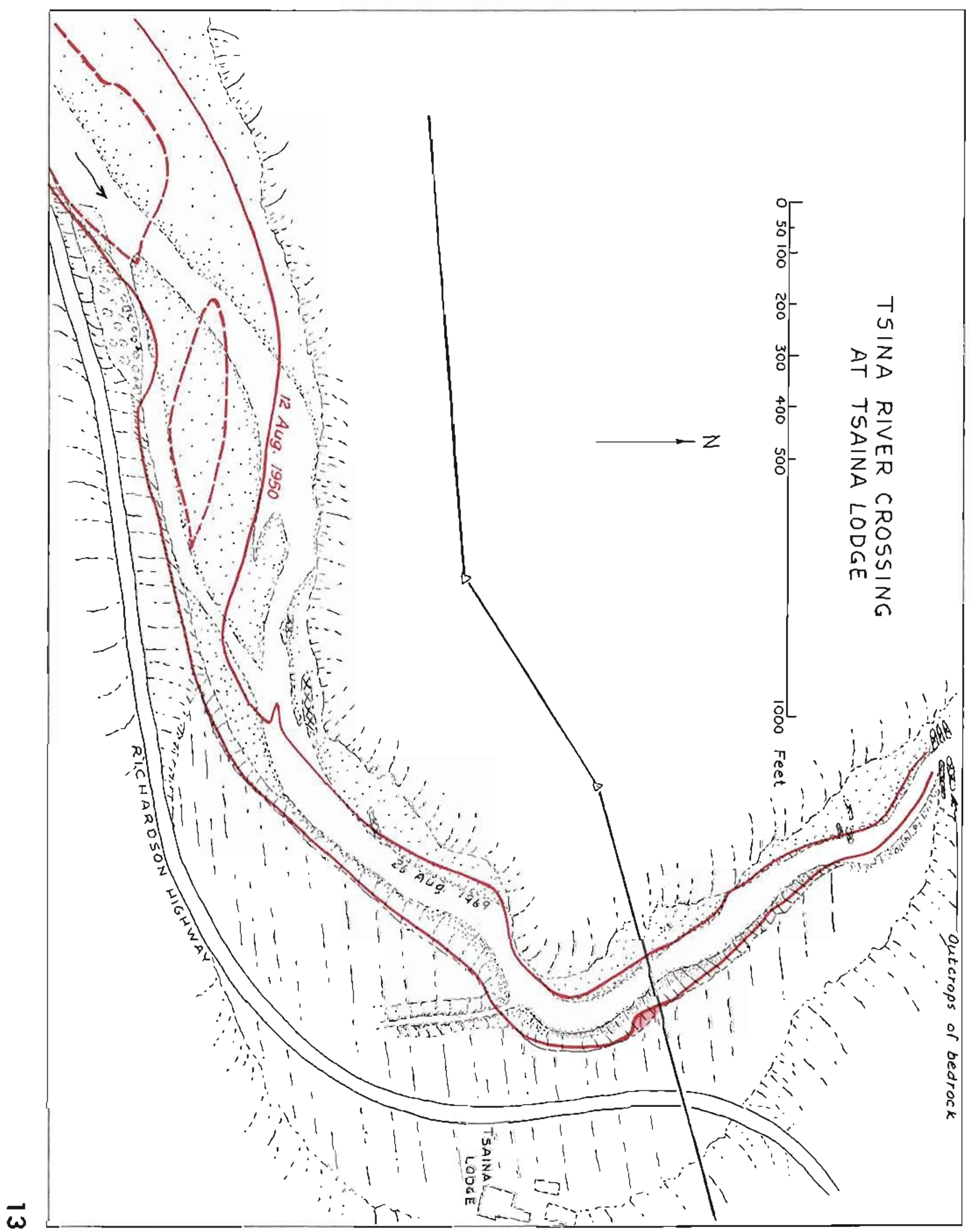




\section{Tsina River Crossing Near Mile 41}

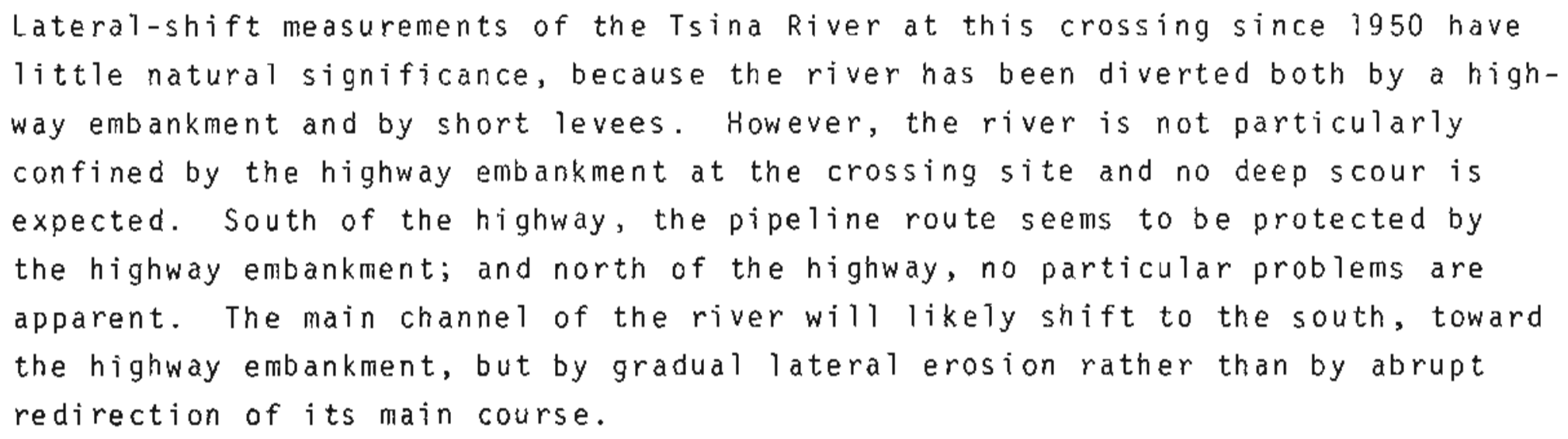




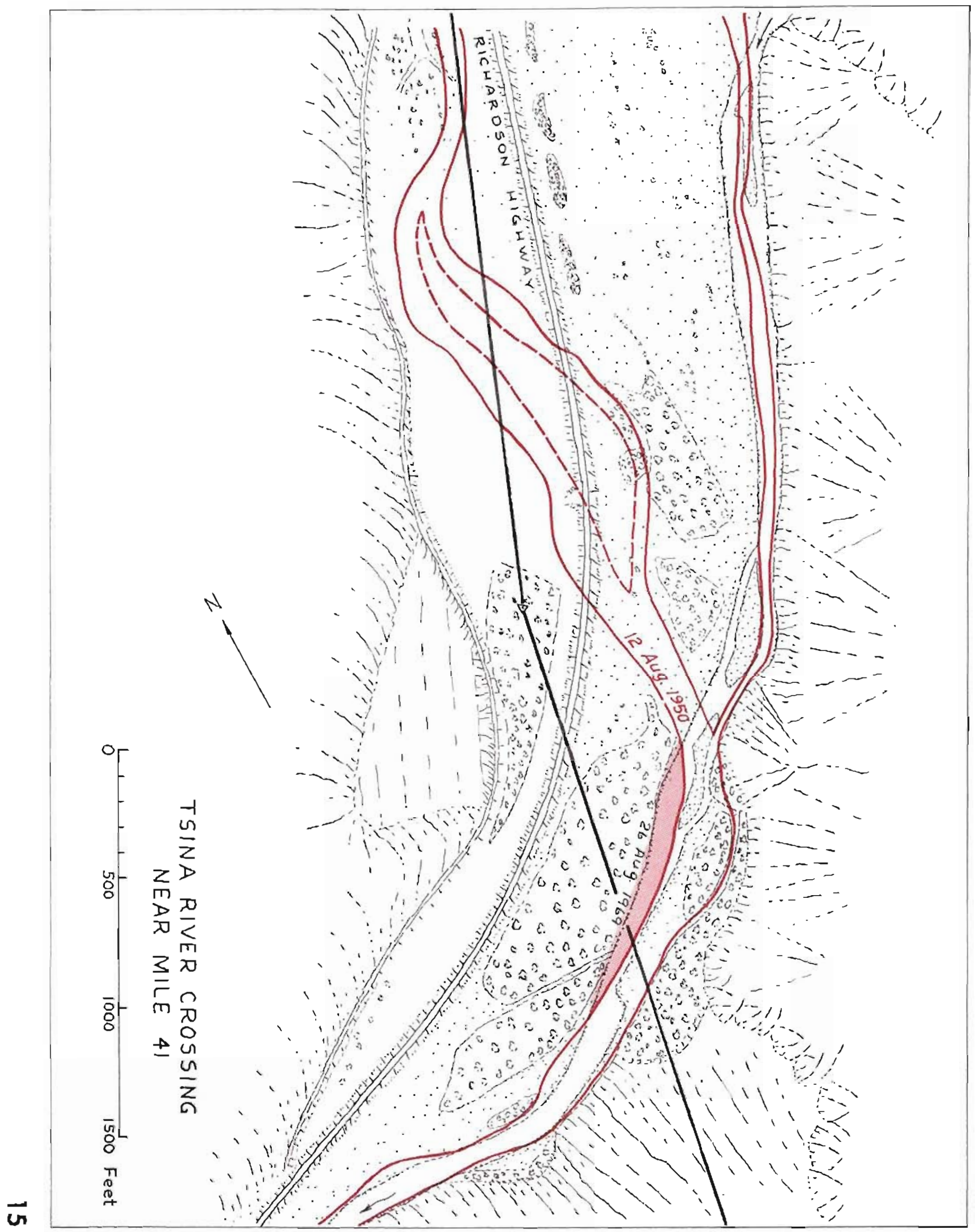




\section{Tonsina River Crossing}

The southern approach of the pipeline to the Tonsina River channel is across a wooded surface that bears the scars of old channels. This surface is regarded as a low terrace, subject to flooding at infrequent intervals (say, on the order of 50 years), but the main channel of the river is unilkely to be redirected abruptly across it. This surface is, however, subject to lateral erosion and at the crossing site the river has trimmed it back for a maximum distance of about 125 feet during the past 20 years. Part of this removal took place by the reoccupation of a side channel, and the erosion rate of about 5 feet per year is considered too large to be projected into the future. Nevertheless, the crossing site is now on the outside of a bend, and an erosion rate of 2 feet per year would not be an excessive estimate. The northern approach to the channel is across a large gravel bar, mostly vegetated and unlikely to be either eroded laterally or the site of the main channel for the next few decades. 


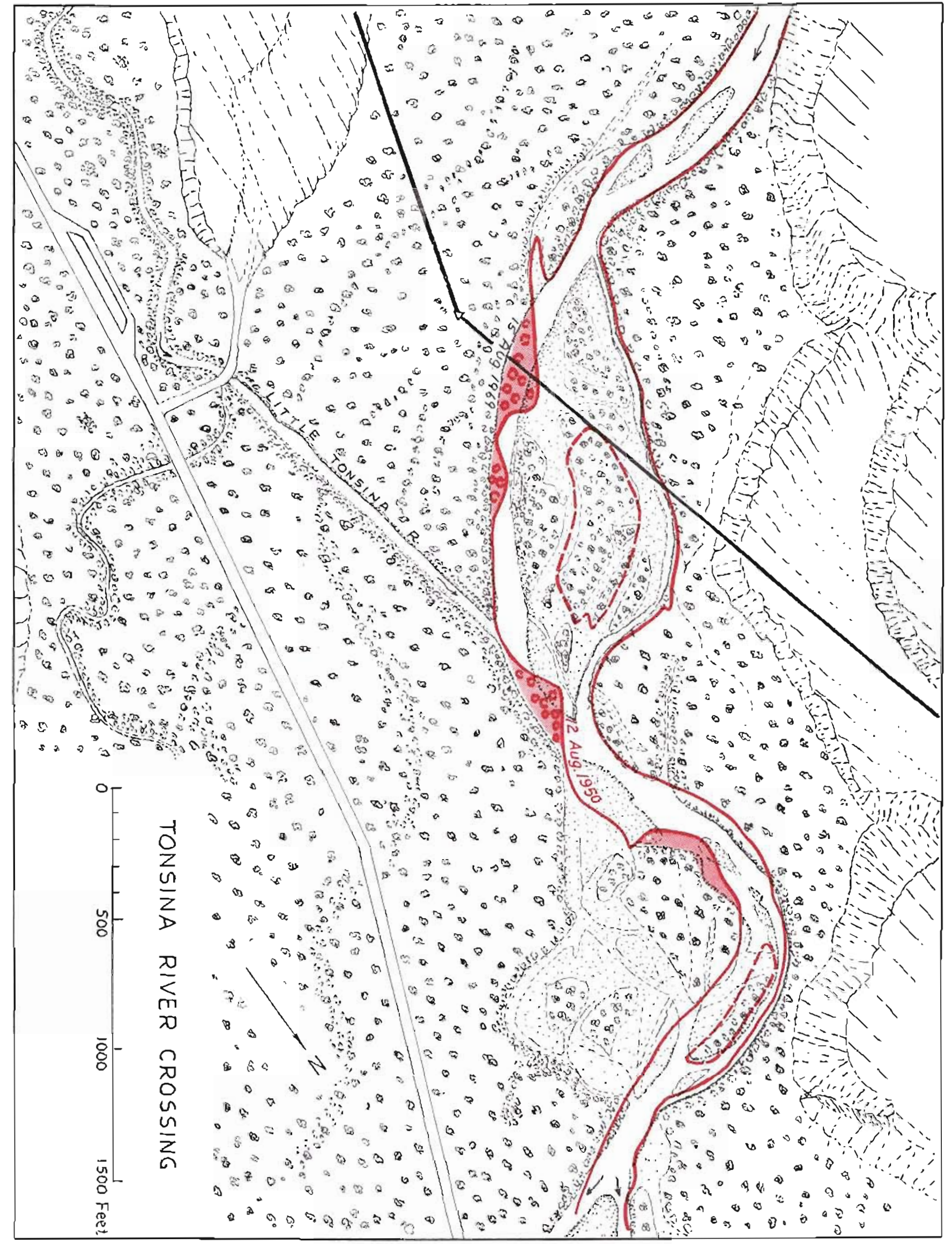




\section{Klutina River Crossing}

The southern approach of the pipeline to the klutina River channel is across a series of poorly defined low surfaces, some marked by old meander scars, which indicate that the recent history of the river has beencone of continuous slow degradation. Areas flooded at intervals of $2-3$ years appear to be confined to a narrow strip along the river. As examined in the field, the channel has an aspect of stability and no significant amount of lateral erosion occurred between 1948 and 1969. The most difficult engineering probiem in approaching the klutina seems to $1 \mathrm{ie}$ in the method of descending the steep terrace face that borders the river on the north. One suggested approach involves the large ravine just downstream from the proposed crossing. It may be pertinent to note that this ravine is not a rapidly eroding feature, as it shows no significant change between 1948 and 1969 . 


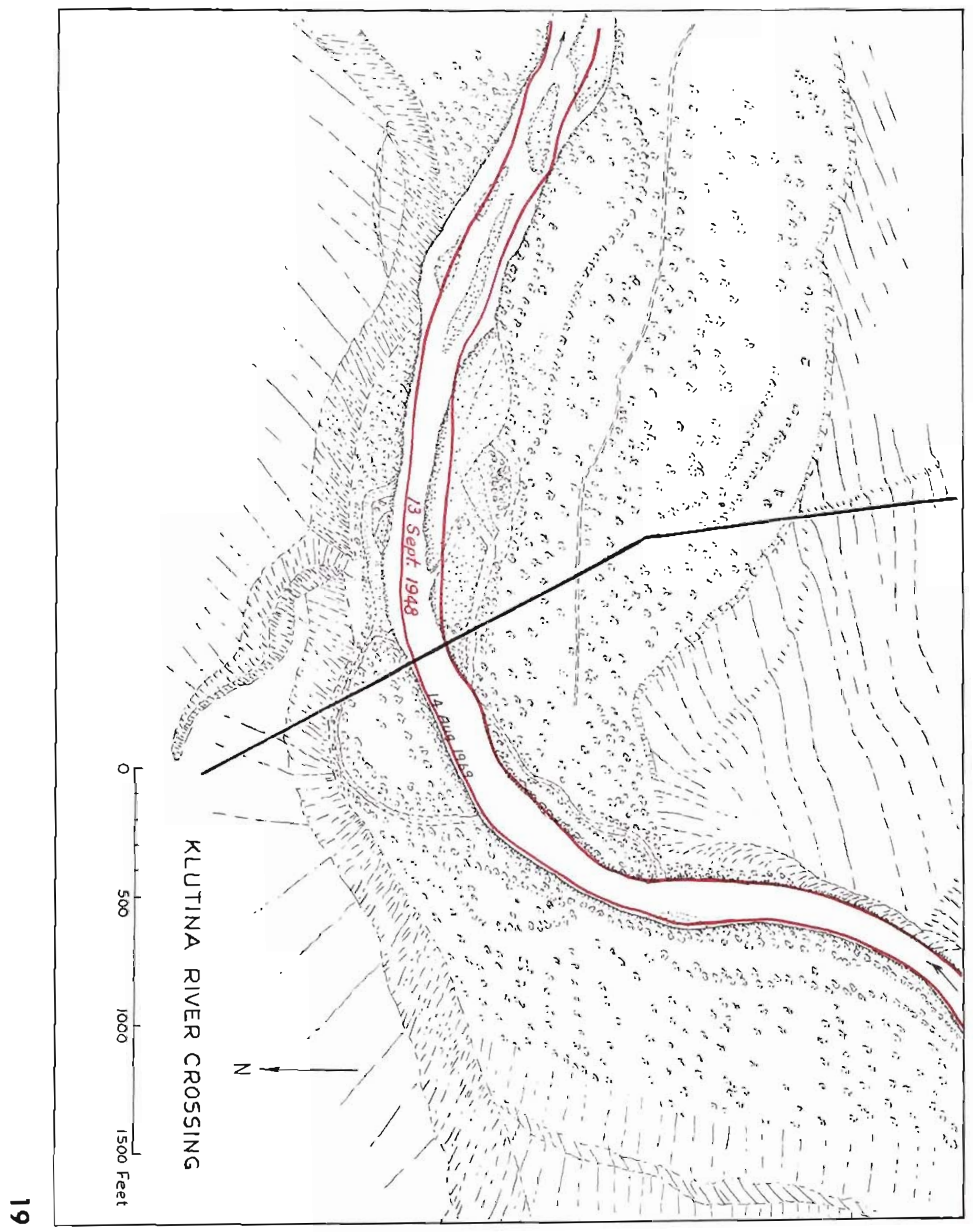




\section{Tazlina River Meander}

A large meander, Tocated about 10,000 feet downstream from the crossing site, is approaching the cutoff stage and questions have been raised as to the scour at the crossing site that would result from cutoff of the meander. The river course would be shortened 8,500 feet by the cutoff, which amounts to about 25 feet of fall.

When the erosional remint at the meander neck is examined by casual comparison of the 1949 and 1969 aerial photographs, 1 ittle change is seen. However, very careful comparison of the photographs at greatly enlarged scale shows that, downstream from the narrowest part of the neck, the remnant has been substantially reduced by about 150 feet of lateral erosion. The point of maximum lateral erosion has shifted downstream from the narrowest part of the neck, where cutoff is most imminent, but a bend is impinging directly against the remnant on its opposite side. The remnant does not consist of consolidated bedrock, but of unconsolidated terrace fill. When all factors are considered, the probabilities are better than even that the bend will be cut off within the next few decades.

However, cutoff of the bend wil not necessarily result in drastic scour at the crossing site. The bedload of the river includes abundant cobbles and boulders and its gradient is in any case not smooth. Cutoffs are common a iong meandering Alaskan rivers, but no evidence of drastic scour (as indicated by increase in bank height) can be observed in the field. For example, on Hess creek upstream from the crossing site, a cutoff (which probably took place in 1967) shortened the river course by 5,350 feet. The river merely widened its channel downstream from the cutoff and no change in bank height could be observed. In general, it seems that the step in gradient due to the cutoff is distributed over a short distance upstream and downstream from the cutoff and part of the excess energy is absorbed by channel widening. Perhaps 5 feet of scour might be expected at the Tazlina crossing site as a result of the cutoff. 


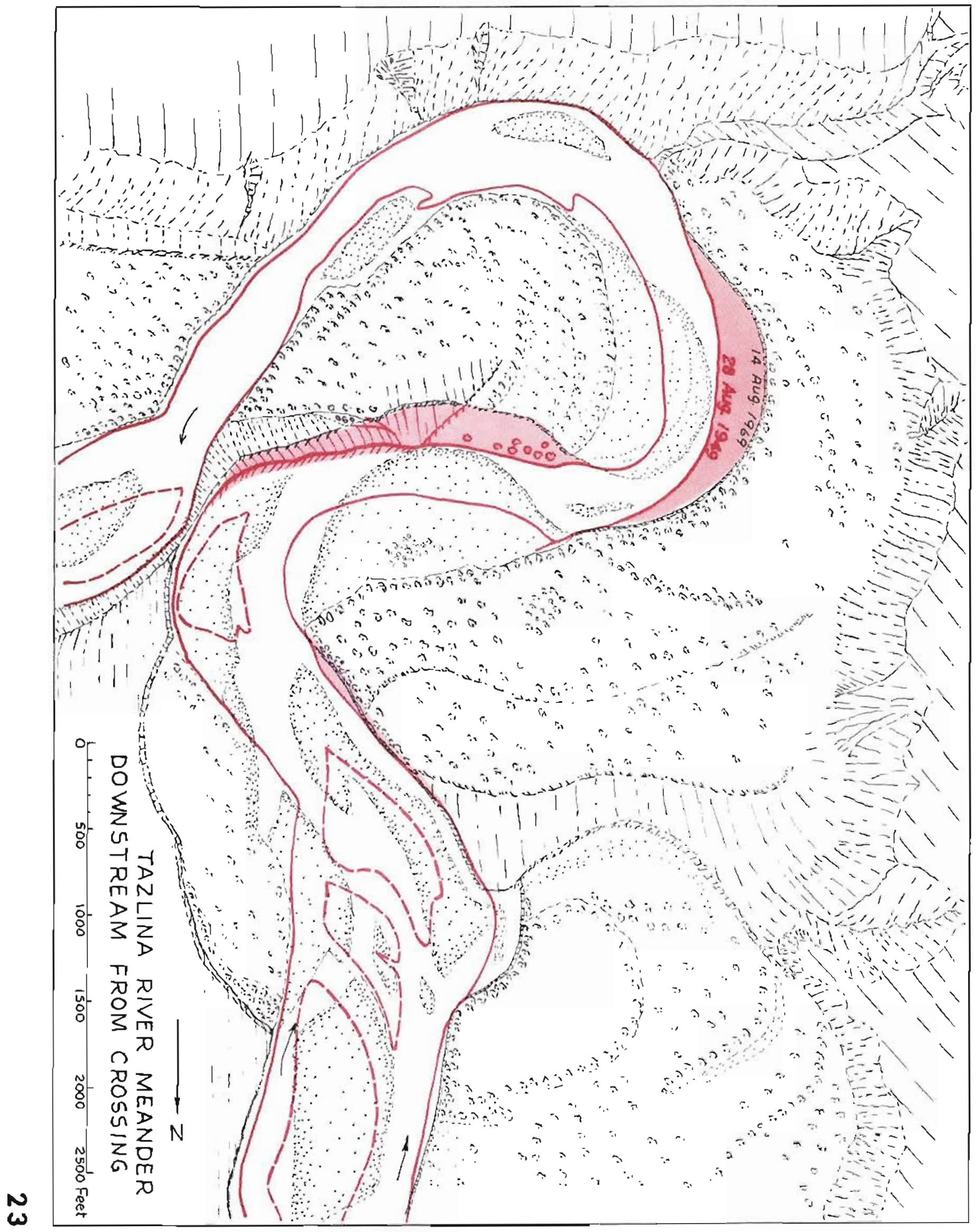




\section{Gulkana River Crossing Near Sourdough}

As with most Alaskan rivers along the pipeline route, the low terraces that border the Gulkana River indicate that it is a slowly degrading stream and that its flood plain is confined to a narrow strip along the river. Lateral erosion has been low to moderate, amounting to a maximum of about 100 feet (1949-69) at the apex of a bend upstream from the crossing site. No significant amount of lateral erosion was discerned at the crossing site, but a cutoff is imminent at the next meander upstream, where the meander neck was reduced from a width of 200 feet in 1949 to a width of 120 feet in 1969. Field examination at high river stage on June 7,1971 , indicated that erosion is proceeding rapidly at this meander neck, and it will probably be cut off within the next few decades. Cutoff wili shorten the river course by about 2,500 feet, and several feet of scour will occur at the crossing site. The new channel made by cutoff would impinge directly against the right bank upstream from the crossing point and the resulting rapid bank erosion would probably extend downstream to the crossing. 


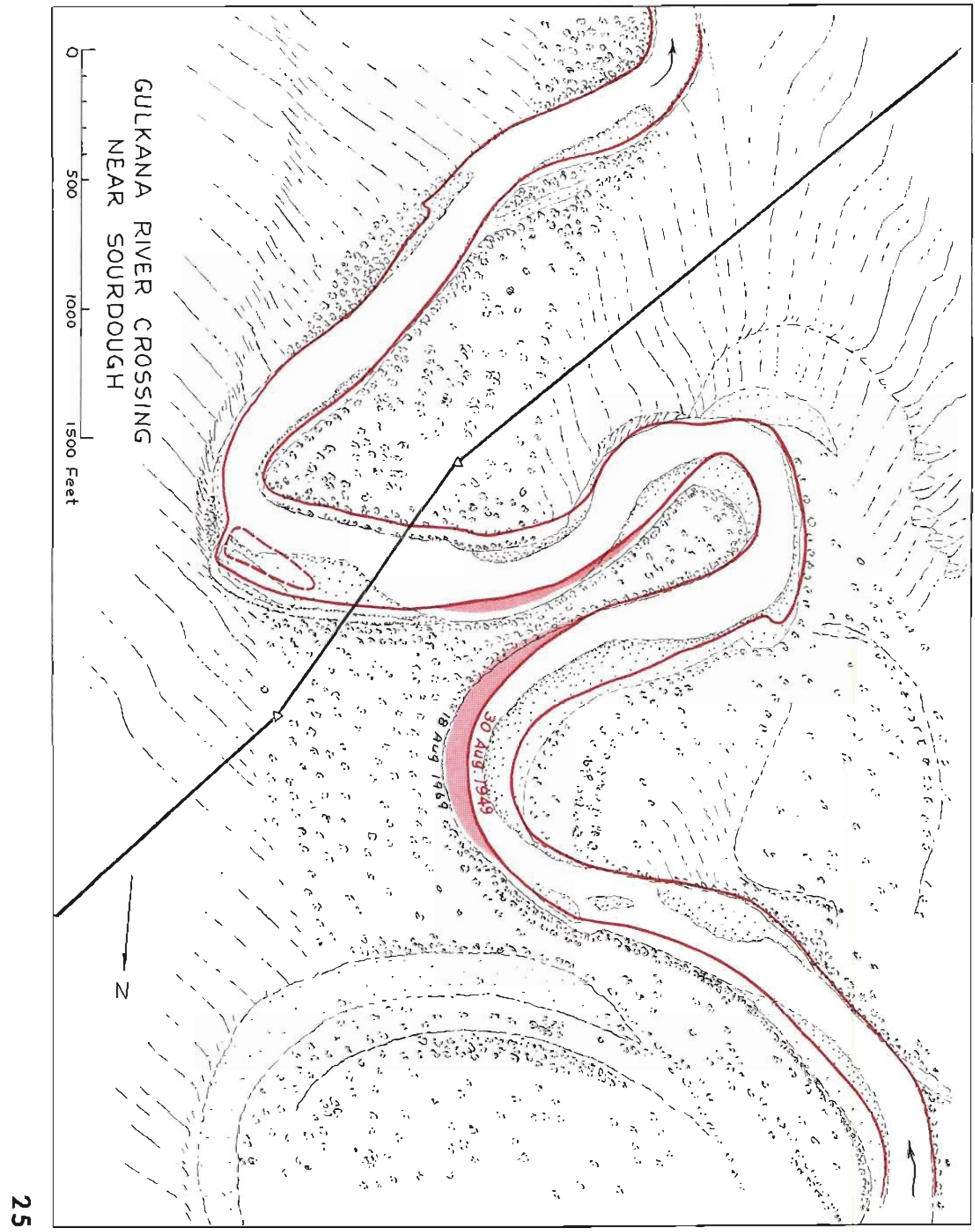




\section{Salcha River Crossing}

The Salcha River crossing site is at the apex of a large meander bend where the concave bank migrated laterally about 225 feet during the period 1950-69. The next bend upstream, which is somewhat narrow, migrated about 300 feet during this same period. In the next few decades, the bend at the crossing can be expected to continue its lateral migration at a rate similar to that of the past. The surface crossed by the pipeline on the convex side of the bend is subject to flooding but not to significant scour because cutoff of the main channel across this surface seems unlikely. 


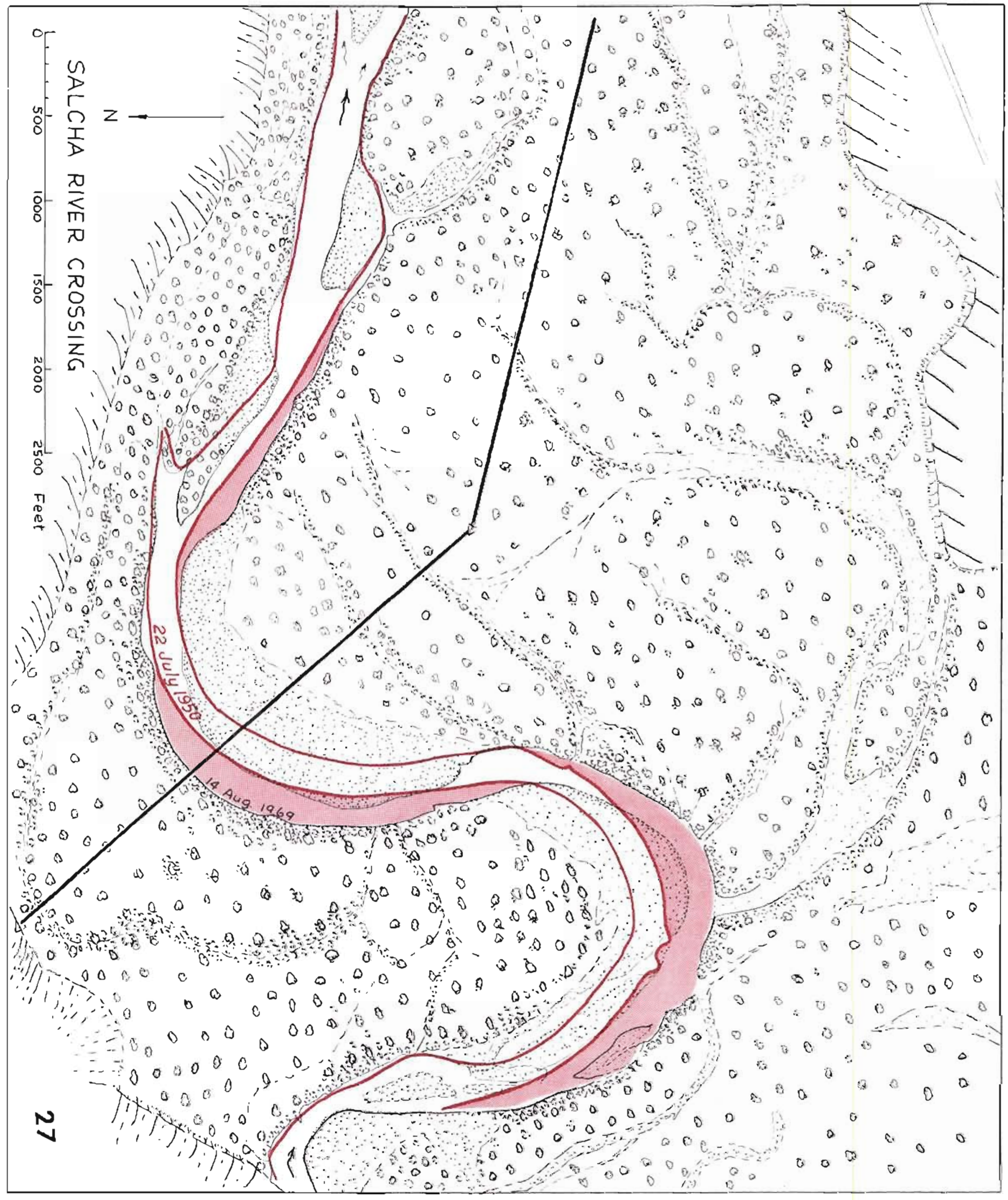




\section{Chatanika River Crossing}

After descending the gently sloping valley sides of the Chatanika River, the pipeline route crosses a valley floor that is nearly flat but not all of which is regarded as flood plain. The outer edges of the valley flat are mantled with colluvium and the flood plain itself seems confined to the meander belt, as marked by the meanders themselves and by many oxbow lakes. The lateral migration rate of the channel was rather low for the period 1951-69, reaching a maximum of about 100 feet at the apex of a narrow bend. About 25 feet of lateral erosion occurred during this period at the crossing site, but a somewhat higher rate there may be expected in the future. An incipient point bar has developed on the north bank at the crossing site, and a new bend appears to be in process of development there.

The banks, which are composed mainly of siity sand and are about 6 feet high, are bordered from place to place by barely visible fissures at distances ranging from a few feet to about 10 feet from the edge of the bank. The fissures apparently mark the edges of blocks that have slumped downward a foot or so toward the river. similar slump blocks along the banks were noted at the kanuti River and at the Little Tonsina, and they are tentatively attributed to the undercutting of frozen silty banks. Obviously, the stability of frozen silt banks--as compared with banks of thawed gravel--is likely to be adversely affected by installation of the pipeline, and some means of bank protection wili be necessary to prevent rapid lateral erosion. 


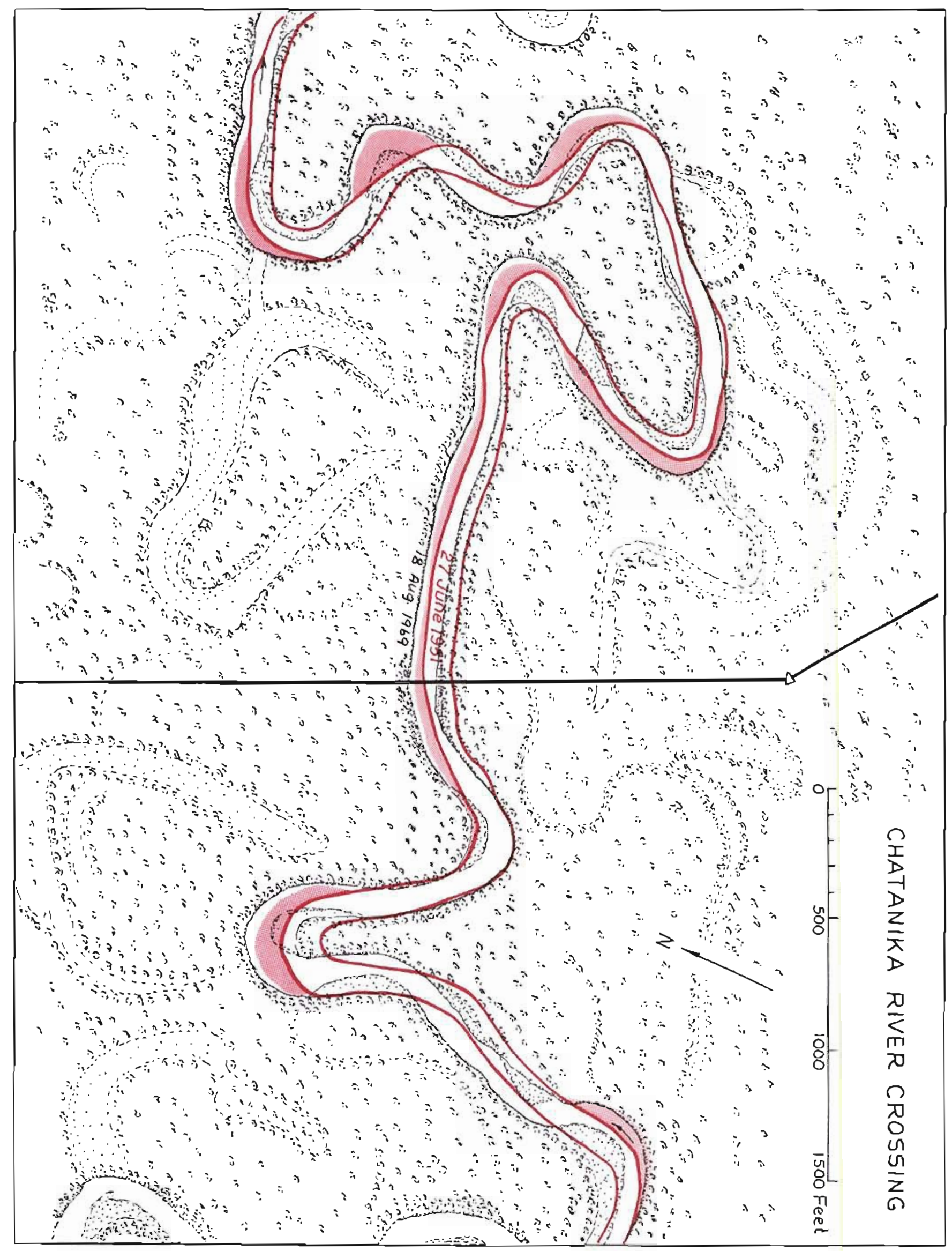




\title{
Hess Creek Crossing
}

\begin{abstract}
The flood plain of Hess creek is roughly defined by its meander belt and includes most of the valley flat crossed by the pipeline route. Lateral erosion rates for the period 1951-69 were generally small and were insignificant at the crossing site. As shown on the map, a substantial channel cutoff has recently (probably in 1967) occurred upstream from the crossing site; no other cutoffs are imminent in the general vicinity. Where examined, the banks are about 7 feet high and consist of medium to fine grave? overlain by a foot or two of silty sand. These gravelly banks are less prone to instability resulting from installation of the pipeline than are the finer-grained banks along such streams as the chatanika, but some means of bank protection will be needed to prevent rapid lateral erosion.
\end{abstract}




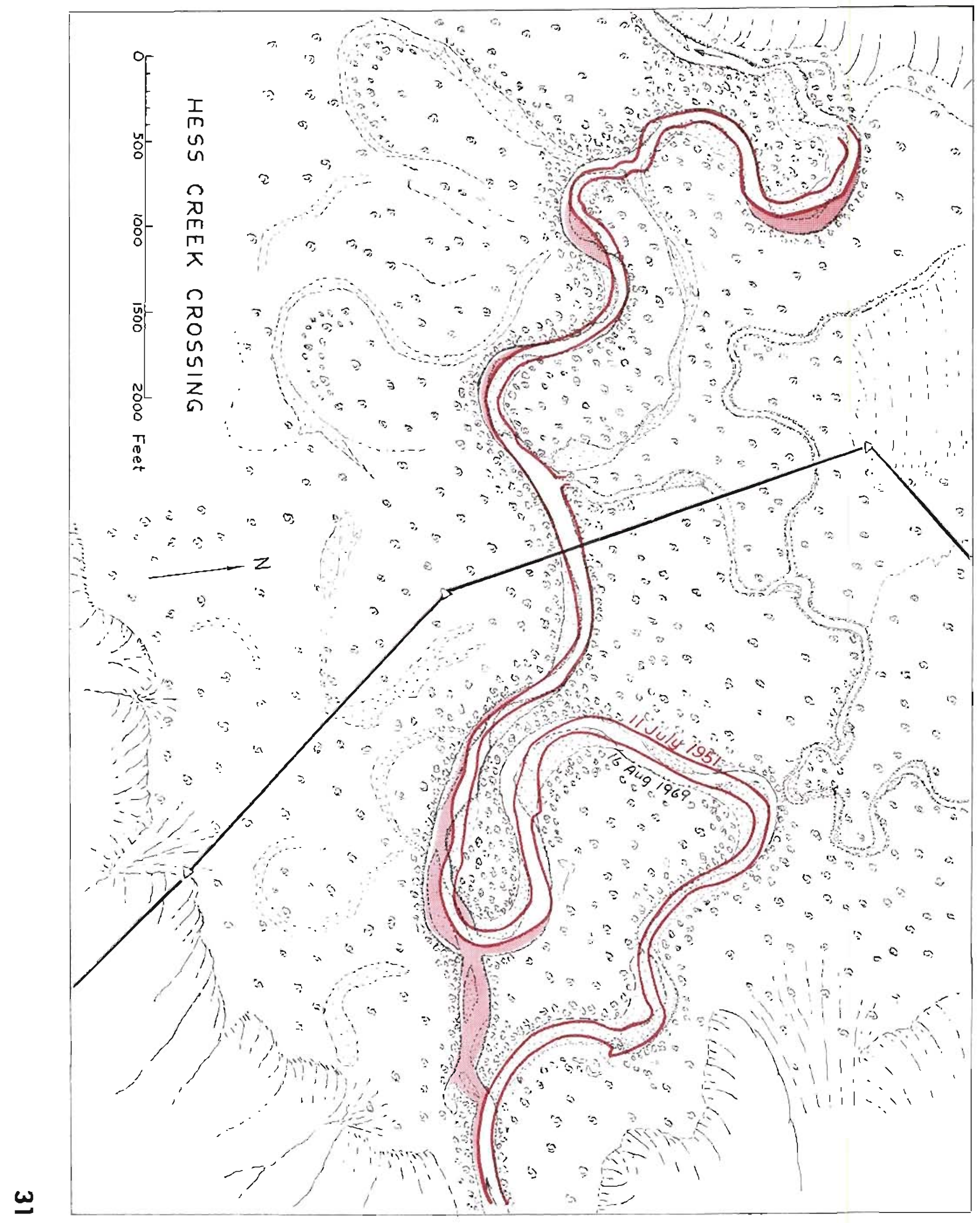




\section{Jim River Crossing}

The pipeline approach on both sides of the proposed river crossing is across a surface that bears the arcuate scars of abandoned channels and is wooded, particularly on the western side, with mature firs. Several minor levels are distinguishable on this surface, ranging in height from about 5 feet above the river to perhaps 12 feet; and these are regarded as a series of low terraces formed as the river slowly degrades its channel. The flood plain of the river consists of a narrow strip sparsely vegetated with birch, balsam poplar, and shrubs, and occurring mainly on the landward edge of point bars. As exposed on point bars, the bedioad of the river consists mainly of cobbles and small boulders; the exposed banks consist mainly of coarse gravel overlain by forest mat.

Upstream from the crossing site, the river has developed a new, rather sharp meander bend since 1955 (date of the earliest available aerial photographs) that has migrated laterally about 125 feet in the direction of the proposed pipeline apprach. Lateral migration at a similar rate in the future can be expected, and it is apparent that about 500 feet of the pipeline would be in jeopardy. Bank stabilization by the use of large riprap would doubtless reduce the rate of lateral migration, but the option of moving the crossing site should be considered. 


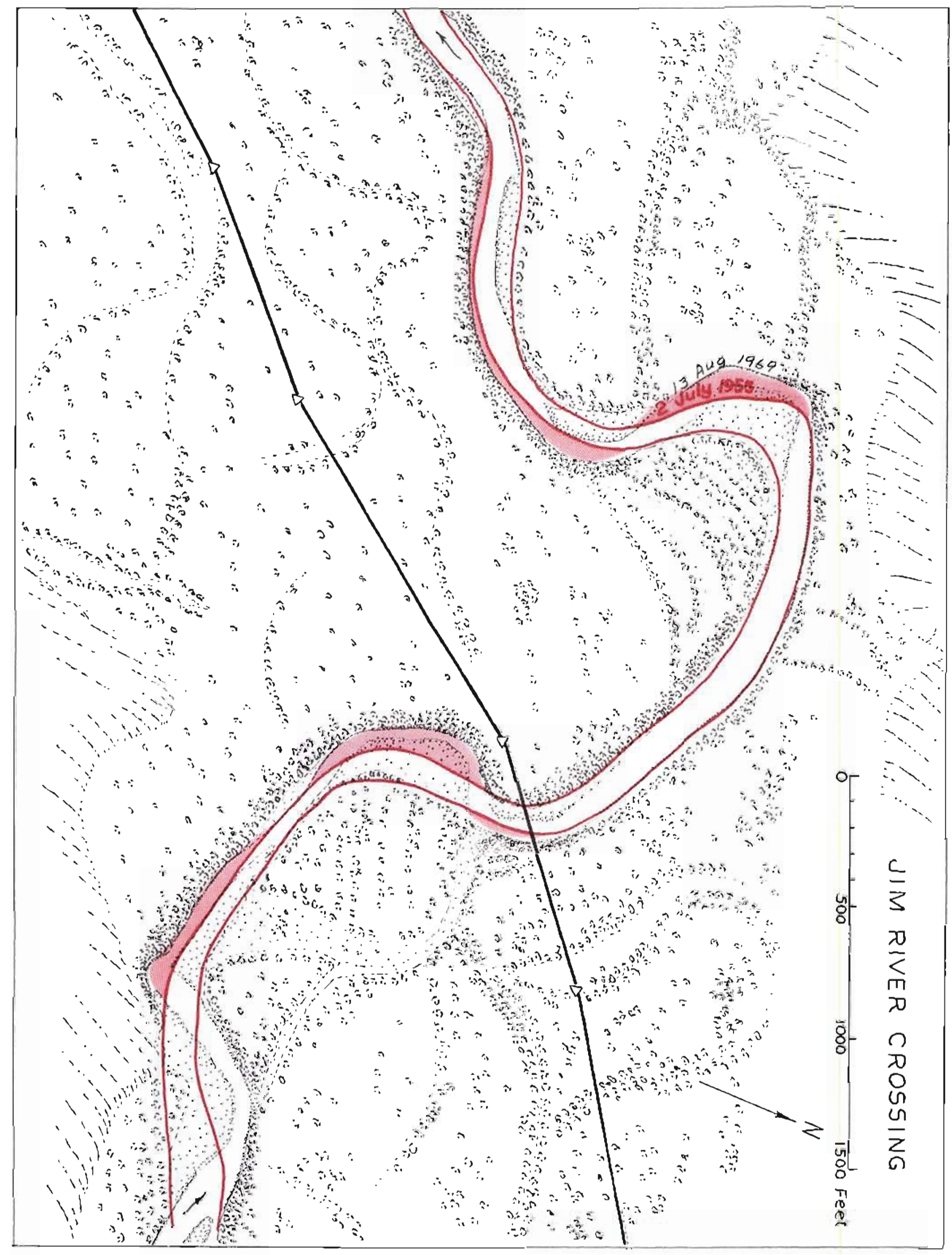




\section{Diefrich River Crossing at Koyukuk River Confluence}

The Dietrich River at this locality occupies the floor of a glaciai trough on the south slope of the Brooks Range. Just downstream from the crossing site is the confluence of the Bettles River, below which the combined rivers are called the Middle Fork of the koyukuk. All three rivers are bordered from piace to place by remnants of low terraces at different elevations, which indicates that the recent history has been one of degradation. The flood plain is difficult to distinguish from low terrace surfaces, but it is probably confined to a narrow strip along the river. The Dietrich River was not observed in the field at this crossing, although it was observed at a point a few miles upstream. The banks and bed material, where observed, are mainly of coarse gravel.

Except for pronounced lateral cutting at a few localities, the river course showed little change between 1955 (date of the earliest available photographs) and 1969. No bank erosion was discerned at the crossing site but about 4,000 feet downstream, where the proposed pipeline route borders the Middle Fork of the koyukuk, the river bank has migrated about 200 feet in the direction of the route. Apparentiy, the river has been migrating in that direction during the last 15 years; and if migration continues, the river would undercut several hundred feet of the pipeline unless it were buried below the depth of scour. 


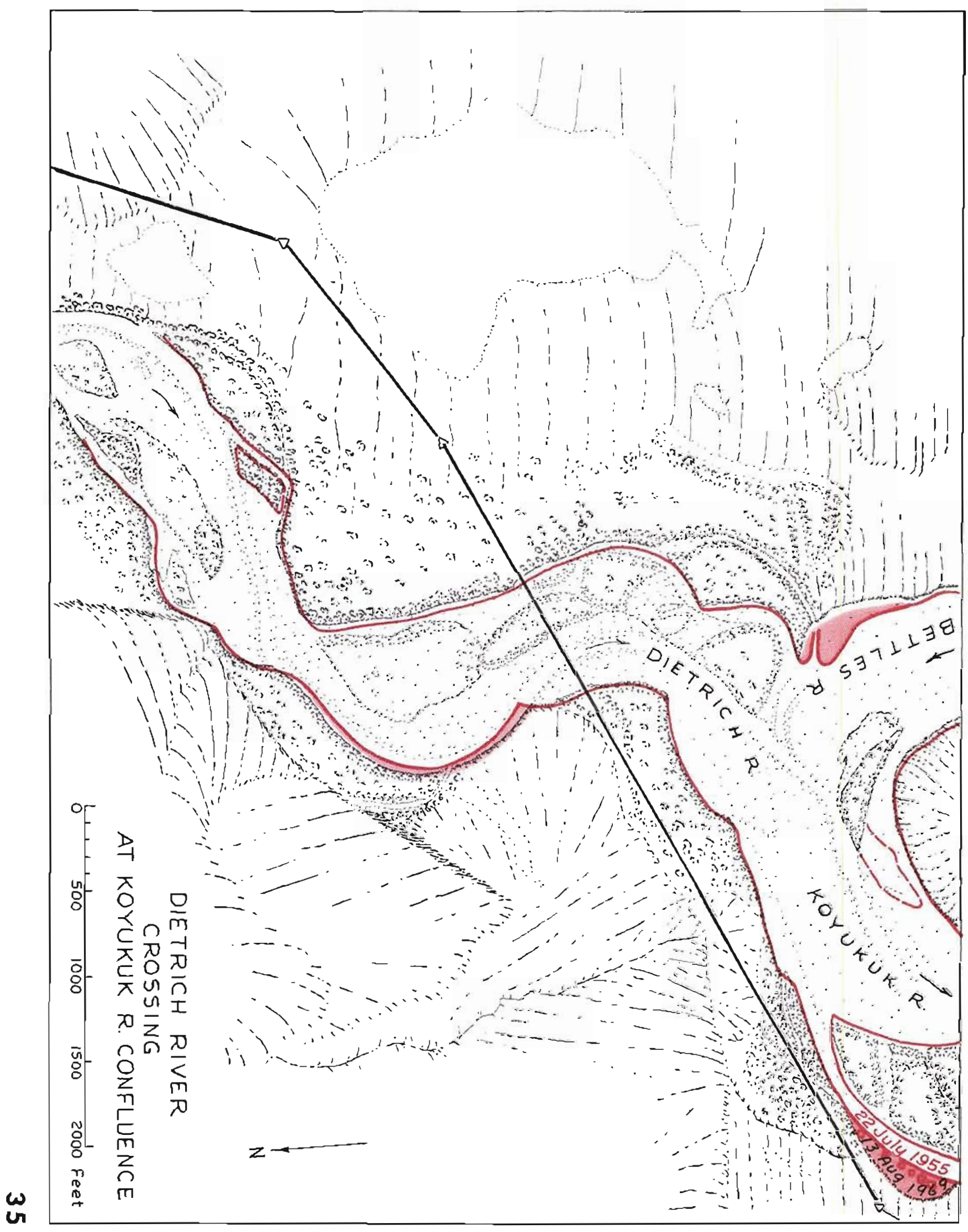




\section{Sagavanirktok River Crossing Near Sagwon}

The western approach of the pipeline route to the river channel is across a nearly flat surface that can be regarded either as a flood plain or a low terrace, but the existence of a fairly recent, abandoned channel on the surface indicates that it is subject to flooding. Diversion of the main channel across this surface within the next few decades is not very probable, although it is subject to lateral erosion. During the period 1949-69, 1ateral erosion--amounting to a maximum of about 300 feet--has occurred mainly on the opposite (eastern) side of the main river channe 1.

On the eastern side of the river channel, the pipeline route is mainly on the flood plain. It crosses channels whose unvegetated condition indicates that they are still transmitting floodwaters, although they are in process of being abandoned as the channel shifts westerly. Abrupt diversion of the main channel across this surface under natural conditions is not very probable, although diversion could be promoted by the trench constructed for burial of the pipeline. Under such circumstances, where the pipeline trench is in approximate alignment with downstream flow in the main channel, special care must be taken to avoid diversion along the pipeline. 


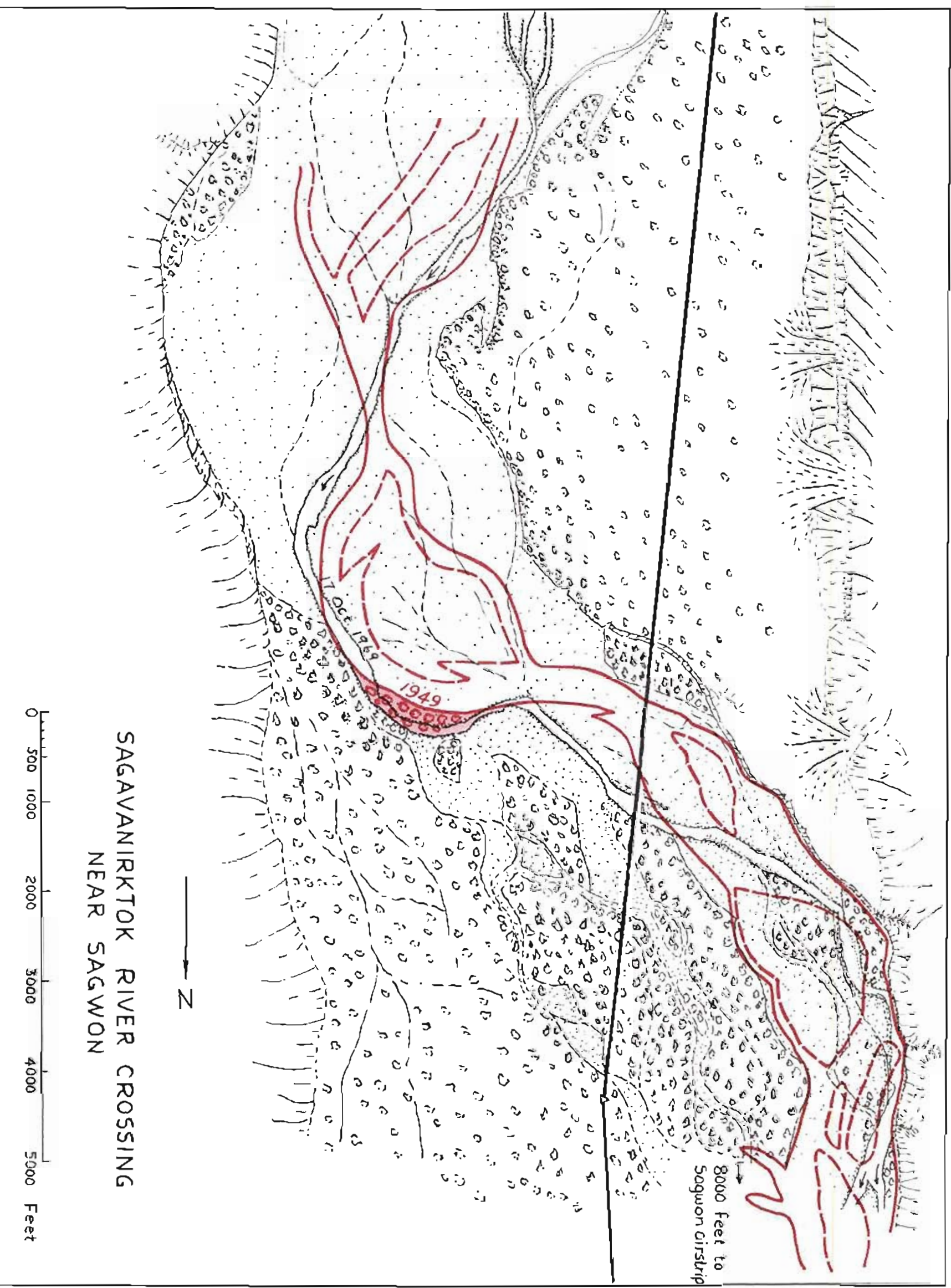




\section{Sagavanirktok River Crossing of lvishak River Confluence}

Approach of the pipeline route to the river channel is across a surface well vegetated with Arctic willow and marked with many abandoned channels, which are indicated by dashed lines on the map. Where examined at a point along the north bank of the channel, this surface stands about 5 feet above the river and is underiain by a layer of organic silt about 1 to 2 feet thick. The tundra mat of roots and mosses is well established in the silt, and is underlain by gravel ranging in size from pebbles to cobbles. In general, this surface can be regarded as the flood plain of the river. The southern (lower) part of it shows only sparse vegetal cover on the earlier photographs, which indicates that it was occupied by a main channel or anabranch perhaps within the 1 ast 50 years. Despite the rigorous climatic conditions in which it operates, the behavior of the Sagavanirktok appears to be typical of braided rivers in lower latitudes. The channel on one side of an island is gradually abandoned and the is land is thus added to the flood plain.

Along the northwestern (upper) side of the map, the river channel is bounded by a terrace that stands 12-15 feet above the river. As seen in cross section, the lower part of the terrace consists of stratified gravel and the upper 6 feet consists of silt, sand, and gravel, capped by tundra mat. I estimate the age of the terrace at several thousand years; and it is scarcely likely to be flooded, aithough it is subject to lateral erosion.

The maximum amount of lateral erosion measured by the period $1949-69$ is about 150 feet for the terrace and about 250 feet for the flood plain. In general, the earlier river course is not very different from the 1969 course. 


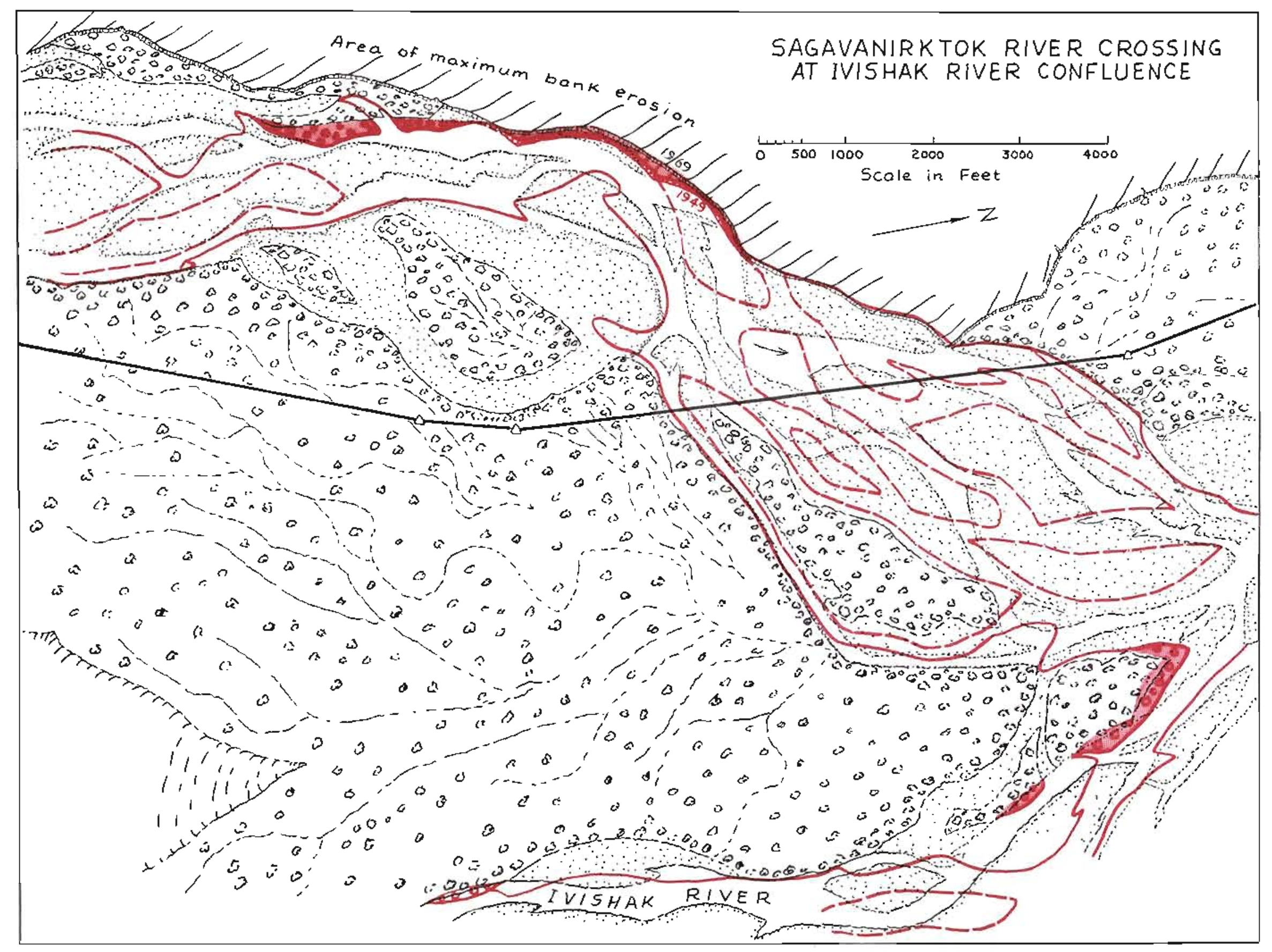




$$
\text { I }
$$

